\title{
Consequentialism and the Possibility of a Confucian-Mohist Encounter
}

\author{
Fang Xudong 方旭東 \\ Professor of Institute for Contemporary Chinese Thought \\ and Culture, East China Normal University, Shanghai, China \\ xdfang@philo.ecnu.edu.cn
}

\begin{abstract}
Mohism and Confucianism are usually characterized as utilitarian and anti-utilitarian, respectively. This article argues that although Confucians do not espouse the kind of utilitarianism found in the Mozi, both Confucianism and Mohism qualify as forms of consequentialism in emphasizing that the outcome of a given behavior or action constitutes the basis for determining whether the latter qualifies as morally good. Through an analysis of the classical texts of the Analects and the Mengzi, I demonstrate that the similarities between the Confucian and Mohist perspectives on $y i$ 義 and $l i$ 利 are much greater than their supposed differences, which have generally been taken for granted. Like Mohism, Confucianism upholds what we might call a "deliberated utilitarianism."
\end{abstract}

\section{Keywords}

Chinese philosophy - Confucianism - consequentialism - Mohism

For a long time, Mohism and Confucianism have been seen as utilitarian and anti-utilitarian in orientation, respectively. As early as 1904, in a text called “The Teachings of Master Mo," Liang Qichao 梁啓超 [1873-1929] compared the ideas of Mozi 墨子 [ca. 468-376 BCE] to the utilitarianism of Jeremy Bentham [1748-1832] and John Stuart Mill [1806-1873] and discerned a form of "pragmatism" or, more literally, a "doctrine of material benefit" [shili zhuyi 實利主義] in the ancient master's thought. In his 1917 Columbia University $\mathrm{PhD}$ dissertation, titled "The Development of the Logical Method in Ancient 
China," Hu Shi 胡適 [1891-1962] used "utilitarianism" as a designation for the Mohist school. Likewise, Feng Youlan's 馮友蘭 [1895-1990] 1923 PhD dissertation, "A Comparative Study of Life Ideals: The Way of Decrease and Increase with Interpretations and Illustrations from the Philosophies of the East and the West," which was also completed at Columbia, contains a chapter titled "Utilitarianism: Mo Tzu." In the first volume of his History of Chinese Philosophy [Zhongguo zhexue shi 中國哲學史] in 1930, Feng continued to use the term "utilitarianism" [gongli zhuyi 功利主義] to characterize the Mohist school. Western scholars such as Angus C. Graham [1919-1991] and Benjamin Schwartz [1916-1999] also saw Mohism as a form of utilitarianism. ${ }^{1}$ That being said, there is certainly no lack of voices critical of the characterization of Mozi as a utilitarianist, in both Chinese and Western scholarship. ${ }^{2}$ Although these critiques have consistently attracted a significant number of rebuttals, consequentialism has never been used as a more appropriate perspective on the Mozi 墨子. The main goal of this article is to explore the encounter between Confucianism and Mohism in terms of their approaches to the problem of consequentialism and involvement in these debates.

In my view, although it is clear that Confucianism does not espouse the kind of utilitarianism found in Mohism, both Confucianism and Mohism qualify as forms of consequentialism in emphasizing that the outcome of a given behavior or action constitutes the basis for determining whether the latter qualifies as morally good. ${ }^{3}$ As is generally known, the classical utilitarianism of Bentham and Mill are paradigmatic examples of consequentialism. Recognizing Mohism as utilitarian thus already implies seeing it as a form of consequentialism. ${ }^{4}$

1 On the English-language scholarship concerning Mozi's utilitarianism, see Nie Tao 聶韜, “Mozi 'gongli zhuyi' sixiang yanjiu de yingyu shuxie 墨子 ‘功利主義”思想研究的英語書寫 [English-Language Scholarship on Mozi's 'Utilitarianism']," Sichuan shifan daxue xuebao 四 川師範大學學報, no. 3 (2015).

2 See, e.g., Hao Changchi 郝長墀, “Mozi shi gongli zhuyi zhe ma? Lun Mojia lunli sixiang de xiandai yiyi 墨子是功利主義者嗎? 論墨家倫理思想的現代意義 [Is Mozi a Utilitarian? On the Contemporary Significance of Mohist Ethics]," Zhongguo zhexue shi 中國哲 學史, no. 1 (2005); Dennis M. Ahern, “Is Mo Tzu a Utilitarian?" Journal of Chinese Philosophy 3 , no. 2 (1976); David E. Soles, "Mo Tzu and the Foundation of Morality," Journal of Chinese Philosophy 26, no. 1 (1999); Daniel M. Johnson, "Mozi's Moral Theory: Breaking the Hermeutical Stalemate," Philosophy East and West 61, no. 2 (2011).

3 There are many different types of consequentialism, but its defining feature is usually understood as the idea that "certain normative properties depend only on consequences." See Walter Sinnott-Armstrong's entry in the online Stanford Encyclopedia of Philosophy: "Consequentialism," last modified June 3, 2019, https://plato.stanford.edu/entries/ consequentialism/.

4 Chris Fraser claims that Mozi abides by "a loose yet sophisticated form of consequentialism" in his entry in the online Stanford Encyclopedia, "Mohism," last modified September 22, 202O, https://plato.stanford.edu/entries/mohism//\#ethics/. 
As such, this article focuses on making clear that Confucian thought qualifies as consequentialist in nature as well.

I can easily imagine that characterizing Confucianism as a form of consequentialism provokes a sense of disbelief as well as downright opposition by some. Even people with only a modest understanding of Confucian thought immediately bring up the fact that "the Master rarely expressed his views on $l i$ 利 [benefit, profit, profitableness, advantage], ming 命 [mandate], and ren 仁 [humaneness],"5 of the idea that "the exemplary person understands $y i$ 義 [rightness], whereas the petty person understands $l i{ }^{\prime \prime}$ or of Mencius's exclamation: "Why must the king speak of benefit? I have only [teachings concerning] humaneness and rightness"7 and many other similar statements. In effect, my article sets out to challenge this rather stereotypical image. Through an analysis of the classical texts of the Analects and the Mengzi 孟子, I show that the similarities between the Confucian and Mohist perspectives on $y i$ and $l i$ are much greater than their supposed differences, which are usually taken for granted. The first section deals with the position of Confucius and the second with that of Mencius. In the conclusion, I discuss the perspective of Dong Zhongshu 董仲舒 [ca. 179-104 BCE].

\section{$Y i$ and $L i$ as Mutually Constitutive Terms: A Reexamination of Confucius's Standpoint}

In the passage "the Master rarely expressed his views on profit, the mandate, and humanness" (Analects 9.1) quoted earlier, the character han 罕 is generally understood as meaning "rarely" or "seldom." The real crux in understanding this passage is how we interpret the word $l i$. If we see $l i$ as referring to something negative, the fact that Confucius "rarely expressed his views" on this matter would imply that the Master preferred not to bring it up. This approach is not suitable for the context of the entire passage, however, because Confucius obviously did not consider "humaneness" a bad thing. In an attempt to arrive at an adequate interpretation, some scholars have framed the problem as one of punctuation. Wang Ruoxu 王若虛 [1174-1243], in Resolution of Various Errors [Wumiu zabian 誤謬雜辨], and Shi Shengzu 史繩祖 [fl. 1241], in Notes from My

5 子罕言利與命與仁. Translation, with modifications, taken from Edward Slingerland, Confucius: Analects, with Selections from Traditional Commentaries (Indianapolis: Hackett, 2003), 86. - Trans.

6 Translation, with modifications, taken from Edward Slingerland, Confucius: Analects, with Selections from Traditional Commentaries, 35. - Trans.

7 Translation, with modifications, taken from Irene Bloom, trans., and Philip J. Ivanhoe, ed., Mencius (New York: Columbia University Press, 2009), 1. - Trans. 
Study [Xuezhai zhanbi 學齋占畢], both parse this sentence in the Analects as 子罕言利, 與命, 與仁, 8 with $y u$ 與 meaning “to praise" or "to commend" here ("the Master spoke appraisingly of the mandate and humaneness"). However, this reading fails to offer a convincing explanation for why Confucius would be inclined to "rarely speak of li." In other words, it does not allow us to conclude that this reticence was the result of his disgust or disdain for "benefit" or "profit." In fact, these attempts at repunctuation are quite unnecessary, because we already have adequate interpretations of the difficulty in question in some earlier annotations of the Analects. As Xing Bing 邢员 [932-1010] writes:

Han means "rarely," $y u$ means "to attain." Li refers to "the harmonizing of what is right." Ming refers to the heavenly mandate. Ren is the highest form of conduct achievable. Because ordinary people are but rarely able to attain li, ming, and ren, Confucius did not often speak of these things. ${ }^{9}$

The crucial point in Xing's interpretation is his gloss of li as referring to a "harmonizing of what is right” [yizhi he 義之和], a phrase he takes from the Book of Changes [Yijing 易經]. This matches the positive connotations of ming and ren as things beyond the reach of ordinary people ("ordinary people are rarely able to attain them"), which Confucius would not be inclined to talk about lightly (he "rarely expressed his views" on these matters). Xing's entire interpretation is straightforward and consistent.

Apart from the description of $l i$ as "a harmonizing of what is right," the Commentary on the Book of Changes [Yizhuan 易傳] contains another passage (in the "Remarks on the Text [Wenyan 文言]"), according to which "bringing benefit to things is in accordance with rightness."10 Xing establishes a connection between these two phrases in the Book of Changes by his reading of $l i$ $w u$ 利物 as "bringing benefit to all things" or "bringing benefit to the myriad things" and his interpretation of he yi 和義 as “a harmonizing of what is right."11

8 Quoted in Yang Bojun 楊伯峻, Lunyu yizhu 論語譯注 [An Annotated Translation of the Analects] (Beijing: Zhonghua shuju, 2006), 99.

9 HeYan 何晏, annot., and Xing Bing 邢旵, comm., "Lunyu zhushu 論語注疏 [Annotations on the Analects]," in Shisan jing zhushu 十三經注疏 [Annotations and Commentaries on the Thirteen Classics], ed. Ruan Yuan 阮元 (Shanghai: Shanghai guji chubanshe, 1997), 2489.

10 Wang Bi 王唱, annot., and Kong Yingda 孔穎達, coll., "Zhouyi zhengyi 周易正義 [The Correct Meaning of the Books of Changes with Subcommentary]," in Shisan jing zhushu, 15 .

11 He Yan and Xing Bing, "Lunyu zhushu," 2489. 
We note that the interpretations of the statement "originating and penetrating, beneficial/advantageous and firm" [yuan heng lizhen 元亨利貞 $]^{12}$ offered for the hexagram qian 乾 in the "Remarks on the Text" is also invoked by the Duchess Mu Jiang 穆姜 in the Zuo Commentary on the Spring and Autumn Annals [Zuozhuan 左傳] (in the ninth year of Duke Xiang 裹公). ${ }^{13}$ According to the Qing dynasty scholar Liu Baonan 劉寶楠 [1791-1855], statements such as "profitable refers to the harmonizing of what is right" and "bringing benefit to things is in accordance with rightness" "are ancient maxims passed down by tradition, which is why I rely on them in my annotations"; 14 and he quotes a significant number of other ancient texts in proving that the original meaning of li was "a harmonizing of what is right":

In Discourses of the Zhou, for instance, we read: "speaking of rightness necessarily involves what is beneficial." Wei Zhao comments: "Only if it brings benefit to human beings and all affairs can we speak of rightness." This goes to show that the earliest meaning of the character li was "a harmonizing of what is right."15

It is noteworthy that, apart from the passage in the Discourses of the States [Guoyu 國語] concerning the relation between $y i$ and li quoted by Liu Baonan, we also find the sentence "benefit can keep rightness in check" in Discourses of

12 English translation of this section is taken from James Legge, trans., The Book of Changes, https://ctext.org/book-of-changes/ens?searchu=\%E5\%85\%83\%E4\%BA\%A8\%E5\%88\% A9\%E8\%B4\%gE/.

13 Hong Liangji 洪亮吉, Chunqiu zuozhuan gu 春秋左傳詁 [Interpretation of the Spring and Autumn Annals and the Zuo Commentary], coll. Li Jiemin 李解民 (Beijing: Zhonghua shuju, 1987), 511.

14 Liu Baonan 劉寶楠, Lunyu zhengyi 論語正義 [Correct Meaning of the Analects], coll. Gao Liushui 高流水 (Beijing: Zhonghua shuju, 199o), 319 .

15 Liu Baonan, Lunyu zhengyi, 319. Xu Shen 許慎 [ca. 58-148 BCE] says in the Shuowen jiezi 說文解字 [Explaining Graphs and Analyzing Characters]: “ $L i$ 利 means 'sharp' [xian 銛]. When a knife is harmonized, it becomes sharp 刀和然後利. The character is composed of 'knife' [dao 刀] and a simplified form of the character he 和. The Book of Changes says that ' $l i$ is the harmonizing of what is right." Duan Yucai 段玉裁 [1735-1815] notes: "When the Shuowen jiezi says that 'when a knife is harmonized, it becomes sharp,' this refers to the original meaning of $l$; the quotation from the Book of Changes is the derived meaning," in Shuowen jiezi zhu 說文解字注 [Annotated Edition of Explaining Graphs and Analyzing Characters] (Beijing: Zhonghua shuju, 2013), 180. Regardless of what the original meaning of the character $l i$ 利 may have been, we can safely assume that, after the Han period [206 $\mathrm{BCE}-220$ ], its meaning was always interpreted with reference to the passage in the Book of Changes [Yizhuan 易傳], in which it is identified as a "harmonizing of what is right." 
the Zhou. ${ }^{16}$ If the "Remarks on the Text" use the concept of yi to explain li, the Discourses take the opposite approach. These two historical documents indicate that $y i$ and $l i$ were seen as mutually constitutive terms in ancient China.

With respect to the passage "the Master rarely expressed his views on profit, the mandate, and humanness," it seems we have sufficient grounds for interpreting the meaning of the term li here on the basis of its mutually constitutive relation to $y i$ as argued above. However, in another passage in the Analects, we find the Master claiming that "the exemplary person understands rightness, whereas the petty person understands benefit." ${ }^{17}$ If we are correct in assuming that $y i$ and $l i$ are mutually constitutive concepts, why then would Confucius use these terms to draw a normative distinction between "the exemplary person" [junzi 君子] and the "petty person" [xiaoren 小人]?

Liu Baonan was well aware of this problem and argued that Confucius drew this distinction in order to indicate the radically different ways in which an "exemplary" and "petty person" understand $l i$. That is, the type of "benefit" on which Confucius "rarely expressed his views" is only superficially similar to the kind of "benefit" that "the petty person understands." Liu's close predecessor, Jiao Xun 焦循 [1763-1820], however, believed that the meaning of $l i$ is identical in both passages in the Analects but differs from how this concept is used in the phrase "benefit is the harmonizing of what is right" in the Book of Changes. In the Book of Changes, li means "bringing benefit to things," whereas in the Analects it refers to "bringing benefit to oneself." 18 Jiao's take on the idea that "the Master rarely expressed his views on li" stands apart from most other traditional interpretations. In his view, by the time of Confucius, people had come to understand "benefit" as "benefitting oneself." By contrast, the Master wanted to return to the approach of the ancients and interpreted "rightness" as the proper form of "benefit" or, in other words, saw "benefit" as "rightness." For Jiao Xun, this explains why Confucius usually tried to avoid speaking of $l i$. Put differently, the "benefit" on which "the Master rarely expressed his views" refers to its usual sense as "benefitting oneself." The problem with Jiao's interpretation of this phrase, however, is how to reconcile it with the rest of the sentence in the Analects 9.1.

Comparatively speaking, the interpretation offered in older commentaries that refer to the phrase "benefit is the harmonizing of what is right" in the Book

16 Xu Yuangao 徐元誥, Guoyu jijie 國語集解 [Collected Commentaries on the Discourses of the States], coll. Wang Shumin 王樹民 and Shen Changyun 沈長雲 (Beijing: Zhonghua shuju, 2002), 88-89.

17 He Yan and Xing Bing, "Lunyu zhushu," 2471.

18 Jiao Xun 焦循, Mengzi zhengyi 孟子正義 [The Correct Meaning of the Mengzi], coll. Shen Wenzhuo 沈文倬 (Beijing: Zhonghua shuju, 1987), 418. 
of Changes is more convincing. That said, as indicated above, approaching $y i$ and $l i$ as mutually constitutive terms does not lead to an adequate interpretation of the idea that "the exemplary person understands $y i$, whereas the petty person understands $l i$ " in the Analects 4.16. Regardless of how we understand the difference between these two types of persons, "understanding $y i$ " and "understanding $l i$ " are clearly presented as opposites here. In sum, if $l i$ is understood as denoting something positive, why would there be anything unbecoming about a "petty person" being interested in and mastering ("understanding") it?

We have to recognize that a certain tension is at work here: on the one hand, li is presented as having a positive value, but, on the other hand, it is also suggested that it should not be the center of attention. What, if any, fundamental difference is there between being preoccupied with and motivated by $y i$ and li, respectively?

We find a suitable answer to this question in interpretations of the exclamation "why must the king speak of benefit" in the Mengzi offered by commentators such as Zhu Xi 朱喜 [1130-1200]. In the "Collected Commentaries on the Analects [Lunyu jizhu 論語集注]," Zhu does not follow the traditional interpretations of $l i$ and, instead, employs his usual conceptual distinction between heavenly principle [tianli 天理] and human desire [renyu 人欲] in commenting on the contrast between "understanding $y i$ " and "understanding $l i$ ”: “ $y u$ 喻 means 'to understand.' $Y i$ means what is in accordance with heavenly principle. $L i$ is what is desired by human emotions." 19

Zhu Xi's "Collected Commentaries on the Analects" do not contain any specific comments on the meaning of the word $l i$ in the Analects 9.1 ("The Master rarely expressed his views," etc.). ${ }^{20}$ This makes it difficult for us to determine

19 Zhu Xi 朱喜, “Lunyu jizhu 論語集注 [Collected Commentaries on the Analects],” in Sishu zhangju jizhu 四書章句集注 [Section and Sentence Commentaries and Collected Annotations on the Four Books] (Beijing: Zhonghua shuju, 1983), 73.

20 Zhu Xi's interpretation of this section consists mainly of quotations from the work of the Cheng 程 brothers: “Han 罕 means 'rarely.' The Cheng brothers note: 'Pursuing benefit brings harm to rightness. The profound principle of the mandate, the greatness of the way of humaneness, these things the Master rarely spoke of"' (Zhu Xi, "Lunyu jizhu," 109). According to the interpretation offered by the Cheng brothers, the reason that Confucius rarely expressed his views on ming 命 and ren 仁 was the subtle or weighty nature of these topics, which do not lend themselves to off-the-cuff remarks. Their take on the Master's reasons for rarely speaking of $l i$ differs from most traditional readings in claiming that Confucius believed that giving too much attention to "benefit" would hinder the pursuit of "rightness." However, the Cheng brothers do not further elaborate on why this should be so. This problem would be adequately addressed only by Hu Hong 胡宏, as I discuss later in the main text. Interestingly, in his interpretation of why Confucius rarely 
whether he believed that $l i$ has the same meaning in Analects 4.16 and 9.1. If, in both cases, $l i$ is read as referring to "what is desired by human emotions," which would imply that "exemplary persons" desire it as well, why would Confucius claim that only "petty persons understand li"? In fact, one of Zhu Xi's interlocuters already posed the following question to him: "The actions of an exemplary person surely do not involve a desire for what is not beneficial. Why, then, does the text only speak of petty persons as 'understanding $l i$ '?" In his response, Zhu draws on the interpretation of Hu Hong 胡宏 [Hu Wufeng 胡五峰, 1102-1161]:

Master Hu has already treated this problem in great detail: " $Y i$ is surely that by which $l i$ is gained. This is what the Book of Changes means when it says that 'benefit is the harmonizing of what is right.' However, when an action is undertaken for the sake of benefit, this will lead to the disastrous and irresistible urge to lay claim to more. When a person acts in pursuit of rightness, he can enjoy the benefits of rightness while steering clear of the harms brought on by seeking benefit. This is what is meant by Mengzi's admonition to the King Hui of Liang."21

Needless to say, the admonition mentioned here is "why must the king speak of benefit? I have only [teachings concerning] humaneness and rightness," a passage that we examine in the next section. For now, let us first try to sum up our findings concerning the understanding of $y i$ and $l i$ in the Analects.

As the preceding discussion of the relevant passages in the Analects makes clear, the fact that Confucius "rarely expressed his views on benefit" should not be taken as meaning that he felt disgust or disdain for the idea of $l i$ and was thus reluctant to mention it. Rather, because "benefit," "advantage," and "profitableness" as a "harmonizing of what is right," like the concepts of ming and ren, are beyond the reach of ordinary people, he would not have been inclined to talk about it to just anybody. Interpreting $l i$ in the sentence "an exemplary person understands rightness, whereas a petty person understands benefit" as "bringing benefit to oneself" and thus as something opposed to $y i$ is not consistent with the notion of $l i$ in Analects 9.1. By contrast, the assumption that the use of $l i$ in both passages is consistent and that this term also has a positive

spoke of "benefit," Liu Baonan 劉寶楠 seems to adopt the Cheng brothers' description of the Master's reason for rarely speaking of ming: "The Master rarely spoke of benefit because of the profoundness of its principle" (Liu Baonan, Lunyu zhengyi, 320).

21 Zhu Xi 朱喜, “Lunyu huowen 論語或問 [Questions about the Analects]," in Zhuzi quanshu 朱子全書 [The Complete Works of Zhu Xi] (Shanghai: Shanghai guji chubanshe; Hefei: Anhui jiaoyu chubanshe, 2002), 6:694. 
connotation in 4.16 ("understanding benefit") is reinforced in the Mengzi and allows us to arrive at a consistent interpretation of why Confucius sees the distinction between "understanding rightness" and "understanding benefit" as overlapping with the difference between an "exemplary person" and a "petty person." Another concrete finding from our reading of these two chapters in the Analects is the importance of the ideas that "benefit is the harmonizing of what is right" and "bringing benefit to things is in accordance with rightness" in the "Remarks on the Text." Given the fact that the authorship of this and the other nine commentaries on the Book of Changes is attributed to Confucius, we cannot restrict ourselves to consulting only the Analects while ignoring the "Remarks on the Text" in studying the Master's views on $y i$ and $l i{ }^{22}$

Focusing on the mutually constitutive nature of the terms $y i$ and $l i$ evidenced in the "Remarks on the Text" can be seen as consistent with Mozi's idea that "rightness can bring benefit to human beings." As we read in Sun Yirang's 孫詒讓 [1848-1908] edition of the text of the Mozi:

Master Mozi said: "He Shi's jade, Marquis Sui's pearl, and the nine tripods [ding] are what the feudal lords spoke of as precious treasures. But do they enrich the country, make the people numerous, bring order to government, and bring peace to the nation? I say they do not. Something is spoken of as being valued as an excellent treasure because it can benefit the people. But He Shi's jade, Marquis Sui's pearl, and the nine tripods do

Needless to say, apart from the commentaries on the Book of Changes, further study of Confucius's view on these concepts would require us to take additional classical texts into account. In the Zuo Commentary on the Spring and Autumn Annals [Zuozhuan 左 传] (in the second year of Duke Cheng 成公), for instance, Confucius made the following important statement: "Not long thereafter, the leaders of Wei 卫 rewarded Zhongshu Yuxi 仲叔于奚 with settlements. He declined and requested instead curved frames for suspending musical instruments and the use of martingales of silken cords when he visited court. His requests were granted. Confucius heard of this and said, 'What a pity! It would have been better to give him many settlements. It is precisely ritual objects and names that cannot be granted to others, for these are the things by which a ruler governs. The right names are for bringing forth trust; trust is for guarding ritual objects; ritual objects are for embodying ritual propriety; ritual propriety is for carrying out rightness; rightness is for bringing benefit; benefit is for governing the people. These are the great principles of government. If these things are granted to others, it amounts to handing over government to others. Once the government is gone, then domain and patrimony follow, and the process cannot be stopped"' (Du Yu 杜預, annot., and Kong Yingda 孔穎 達, comm., “Chunqiu zuozhuan zhengyi 春秋左傳正義 [The Correct Meaning of the Zuo Commentary on the Spring and Autumn Annals]," in Shisan jing zhushu, 1893-94). Translation, with modifications, taken from Stephen Durrant, Wai-yee Li, and David Schaberg, trans., Zuo Tradition: Commentary on the Spring and Autumn Annals (Seattle: University of Washington Press, 2016), 712-13, emphasis added. - Trans. 
not benefit people, so, in terms of the world, they are not excellent treasures. Now, if rightness is used in governing the country, the people will certainly be numerous, government will certainly be well ordered, and the nation will certainly be at peace. That which is said to be valued as an excellent treasure is that which benefits the people. And rightness is of benefit to the people. Therefore, I say that righteousness is the world's most excellent treasure." ${ }^{23}$

\section{"Exchanging Mutual Benefit": Reassessing the Concepts of Yi and $L i$ in the Mengzi}

Because Mengzi consistently "repudiated Yang Zhu and Mozi," most people automatically assume that if Mozi is a utilitarian, Mengzi must be opposed to utilitarianism. After all, the Mengzi opens with the famous episode in which the Confucian thinker is admonishing king Hui of Liang 梁惠王 [r. 370-319 ВСE] for "speaking of benefit." However, things are not quite that simple. Let us begin by looking at the original text:

Mencius met with King Hui of Liang. The king said, "Venerable sir, you have not considered a thousand li too far to come. Surely you have some means to benefit our state?" Mencius replied: "Why must the king speak of benefit? I have only [teachings concerning] humaneness and rightness. If the king says, 'How can I bring benefit my state?' the officers will say, 'How can I bring benefit to my house?' and the gentlemen and the common people will say, 'How can I bring benefit to myself?' Those above and those below will compete with one another for benefit, and the state will be imperiled. One who murders the ruler over a state of ten thousand chariots surely will be from a house of a thousand chariots; one who murders the ruler over a state of a thousand chariots surely will be from a house of a hundred chariots. A share of a thousand in ten thousand or a hundred in a thousand is hardly negligible; yet, when rightness is subordinated to benefit the urge to lay claim to more becomes irresistible. It has never happened that one given to humaneness abandons his

23 Sun Yirang 孫詒讓, Mozijiangu 墨子閒詁 [Annotations to the Mozi], coll. Sun Qizhi 孫啓 治 (Beijing: Zhonghua shuju, 2001), 429-30. Translation, with modifications, taken from Ian Johnston, trans., The Mozi: A Complete Translation (Hong Kong: Chinese University Press, 2010), 647-49. - Trans. 
parents or that one given to rightness subordinates the interests of his ruler. Let the king speak only of humaneness and rightness. What need has he to speak of benefit?"24

Many people have taken this celebrated passage as proof of Mengzi's antiutilitarian stance. What Mengzi is opposing here, however, is "speaking of benefit," not li itself. When the text says that "it has never happened that one given to humaneness abandons his parents or that one given to rightness subordinates the interests of his lord," it is speaking of the "benefits" stemming from "humaneness and rightness." Zhu Xi, for one, believes that "what is called humaneness and rightness here are surely beneficial." ${ }^{25}$ The famous early Song Dynasty neo-Confucian philosophers, the Cheng brothers (程影 1032-1085, 程 頣 1033-1107), for their part, argue that what Mengzi opposes is "having a heart that is solely devoted to benefit":

It is not the case that an exemplary person does not desire benefit or advantage but that having a heart solely devoted to benefit is harmful. If one solely pursues humaneness and rightness without seeking benefit, this will still be most beneficial. In the time of Mengzi, the people in the world were exclusively preoccupied with seeking benefit and had forgotten about humaneness and rightness. This is why he only talked about humanness and rightness and not about benefit [as such]. In doing so, he sought for a fundamental solution to the pernicious practices [resulting from the pursuit of benefit]. This is what the mind of a sage must be like. ${ }^{26}$

In claiming that "it is not the case that an exemplary person does not desire benefit," the Cheng brothers clearly affirm the universal human need to pursue certain "benefits," regardless of whether we are dealing with "exemplary" or "petty persons." Zhu Xi's take on the meaning of $l i$ in the Analects 4.16 as referring to "what human emotions desire" is fully consistent with the interpretation of the Cheng brothers. Because $l i$ is a positive good, people will pursue ("desire") it regardless of their moral stature. The difference between "exemplary" and "petty persons" consists of the methods employed it this pursuit and their varying degrees of success: whereas the former "does not pursue benefit but always arrives at what is beneficial," the latter are "exclusively preoccupied with seeking benefit," which should be condemned as "harmful." The same approach is found in the work of Hu Hong:

\footnotetext{
24 Translation, with modifications, taken from Bloom and Ivanhoe, Mencius, 1 - Trans.

25 Bloom and Ivanhoe, Mencius, 1 - Trans.

26 Quoted in Zhu Xi, "Lunyu jizhu," 202.
} 
When [an exemplary person] acts in pursuit of rightness, he can enjoy the benefits of rightness while steering clear of the harms brought on by seeking benefit. when an action is undertaken for the sake of benefit, this will lead to the disastrous and irresistible urge to lay claim to more.

For Zhu Xi as well, "If [an exemplary person] abides by heavenly principle, not actively pursuing benefit will naturally prove to beneficial. If [a petty person] delivers himself over to human desires, his search for what is beneficial will be in vain and can only end up bringing harm."27

As such, according to the interpretations offered by these Song dynasty [960-1279] Confucians, the distinction between "exemplary" and "petty" persons does not consist of whether $l i$ is treated as a desirable good but, rather, of the different methods and results that characterize their pursuit of "benefit." We could say that, whereas a "petty person" pursues "benefit" in a linear fashion, an "exemplary person" does so in a more roundabout and indirect manner. As a result, the former is harmed by "benefit," whereas the latter is not. A "petty person's" pursuit of "benefit" is doomed to failure, while the "exemplary person" will succeed precisely by not setting his mind on "benefit." Perhaps it is this strange twist in the human pursuit of "benefit" that Mengzi is trying to describe to King Hui of Liang, regardless of what his deeper intentions might have been.

What, we might ask, should the king do if Mengzi manages to convince him? Clearly, there is no need for him to abandon his pursuit of "benefit." Rather, he simply has to change and refine his strategy for doing so: the king has to stop openly using the word $l i$ as a slogan ("speaking of benefit," "asking for benefit") and, instead, learn how to speak the language of "humanness and rightness" ("speak of humaneness and rightness"). If we could call the old King Hui a "naïve utilitarian," this new King Hui would have changed into a "shrewd or deliberating utilitarian."

We have no way of knowing what was really in Mengzi's mind, but the speech he delivers before the king seems to boil down to saying: As the ruler of a state, you have to ensure that there is an atmosphere conductive to practicing humaneness and rightness among your subjects. If your subjects become people who practice humaneness and rightness, this will bring you endless benefits. It is noteworthy that Mengzi in no way demands that the king himself becomes a humane and righteous person. Rather, he is simply describing the simple fact that "it has never happened that one given to rightness subordinates the interests of his ruler." Translated into more contemporary jargon, this

27 Zhu Xi 朱喜, “Mengzi jizhu 孟子集注 [Collected Commentaries on the Mengzi]," in Sishu zhangju jizhu, 202. 
means that humane and righteous subjects are a reliable source of advantage for the ruler. That said, it is clear from other passages in the text that Mengzi also wanted rulers to practice a form of "humane government" [renzheng 仁政] and thereby bring benefit to his people. In the following passages for example, we read:

If the king bestows humane government on the people, reduces punishment, and lightens taxes, causing the plowing to be deep and the weeding thorough, the strong will be able to use their leisure time to cultivate filiality and brotherliness. In the home they will serve their fathers and brothers; outside, they will serve their elders and superiors. They can then be made to take up sticks and overcome the strong armor and the sharp weapons of Qin and Chu.... With a person of humanity in a position of authority, how can entrapment of the people be allowed to occur? Therefore, an enlightened ruler will regulate the people's livelihood so as to ensure that, above, they have enough to serve their parents, and, below, they have enough to support their wives and children. In years of prosperity, they always have enough to eat; in years of dearth, they are able to escape starvation. Only then does he urge the people toward goodness; accordingly, they find it easy to comply. ${ }^{28}$

Although it is true that Mengzi describes the advantages of "humane government" from the perspective of the king, the text makes it clear that the people will benefit considerably from such a form of government, which involves lighter punishment, lower taxes, an increase in production that will allow people to care for their parents, spouse, and children, sufficient food and clothing in years of prosperity, no risk of starvation in years of dearth, and so on.

On the one hand, humane and righteous subjects are beneficial to the ruler (king), but, on the other hand, a king who practices humane government will bring great benefits to his people. Using a passage in the Mozi, we could say that the Mengzi conceives of the relation between ruler and subjects as one of "universal mutual love and the exchange of mutual benefit" [jian xiang'ai, jiao xiangli 兼相愛, 交相利]. ${ }^{29}$ This interdependent relation becomes abundantly clear in Mengzi's description of the "shared enjoyment" [tongle 同乐] of the ruler and the ruled:

With your permission, I would like to speak to you about music. Now suppose the king is making music here. Hearing the echoes of the king's bells

28 Translation taken from Bloom and Ivanhoe, Mencius, 5 and 11. - Trans.

29 Translation taken from Ian Johnston, The Mozi: A Complete Translation, 139. - Trans. 
and drums and the sounds of his pipes and flutes, the people, with aching heads and furrowed brows, all ask one another, "Why should our king's fondness for music make life so hard for us? Fathers and sons cannot see one another; older and younger brothers, wives and children are separated and scattered." Now suppose the king is going hunting. Hearing the sounds of the king's chariots and horses and seeing the beauty of the plumage and banners, the people, with aching heads and furrowed brows, all ask one another, "Why should our king's fondness for hunting make life so hard for us? Fathers and sons cannot see one another; older and younger brothers, wives and children are separated and scattered." This is solely because he does not share his enjoyment with the people. Now suppose the king is making music here. Hearing the echoes of the king's bells and drums and the sounds of his pipes and flutes, the people, joyfully and with delighted countenances, all tell one another, "Our king must be quite free of illness, for if he were ill, how would he be able to make music?" Now suppose the king is going hunting here. Hearing the sounds of the king's carriages and horses and seeing the beauty of the plumage and banners, the people, joyfully and with delighted countenances, all tell one another, "Our king must be quite free of illness, for if he were ill, how would he be able to go hunting?" This is solely because he shares his enjoyment with the people. Now, if Your Majesty simply will share your enjoyment with the people, you shall be a true king.... When one takes pleasure in the people's pleasures, the people will also take pleasure in one's pleasures, and when one sorrows over the people's sorrows, they will also sorrow over one's sorrows. One who delights in what the world delights in and sorrows over what the world sorrows over - such a one never has failed to become a true king. ${ }^{30}$

If the king succeeds in "sharing his enjoyment" with the (common) people, they will wish him well. Failing to do so will cause the people to resent him or even bear him ill will. "Shared enjoyment" will result in long and stable rule, whereas, in the worst case, resentment can lead to rebellion. Although Mengzi's initial focus is encouraging the king to practice humane government and the "kingly way" [wangdao 王道], the logic of "tit-for-tat" he describes is quite close to that of Mozi:

If a person loves others then others must, as a result, love that person. If a person benefits others then others must, as a result, benefit that person. 
If a person hates others then others must, as a result, hate that person. If a person harms others then others must, as a result, harm that person. ${ }^{31}$

In sum, the opening chapter of the Mengzi does not call upon us to abandon all interest in "benefit" but, rather, lets us in on a "secret": if individual human beings want to gain certain benefits or advantages, they would do well to follow a more indirect and roundabout strategy and begin with the practice of humaneness and rightness, so that these benefits will come to us naturally. In terms of the relation between ruler and subject, the Mengzi claims that the ruler of a state will profit from the humaneness and rightness of his subjects, while the latter will in turn benefit from the ruler's practice of humane government. In his keen awareness of the principle of "the exchange of mutual benefit," Mengzi does not lag behind Mozi.

\section{3}

\section{Conclusion}

The main conclusion we can draw from analyzing the concepts of $y i$ and $l i$ in the Analects and the Mengzi on the basis of a combined reading of several historical (sub)commentaries is radically different from the prevalent view. Based on the foregoing, we can see that neither Confucius not Mencius is suspicious of the human pursuit of "benefit"; indeed, both affirm it as having a positive value. Moreover, they both use the concept of "benefit" in their definition of "rightness." On the surface, it might appear as if Confucius and Mencius primarily emphasize humaneness and rightness, but, on closer inspection, we find that the ideas of humanness, rightness, and "humane government" are defined primarily in terms of "benefit." To a certain extent, the reason that later Confucians appear to have adopted a more anti-utilitarian stance traces back to the influence of Dong Zhongshu and his notion that one should "rectify one's sense of what is right without calculating benefit and clarify the way without striving for success." This formulation has its origin in the biography of Dong in Ban Gu's 班固 [32-92] History of the Former Han [Hanshu 漢書], which says that "a humane person rectifies his sense of what is right without calculating benefit and clarifies the way without striving for success." ${ }^{2}$ These phrases appear in a slightly different form in the Luxuriant Gems of the Spring and Autumn [Chunqiu fanlu 春秋繁露]: "a humane person is one

31 Translation taken from Johnston, The Mozi, 141. - Trans.

32 Ban Gu 班固, Hanshu 漢書 [History of the Former Han], annot. Yan Shigu 顔師古 (Beijing: Zhonghua shuju, 1962), 2524. 
who corrects the way but does not calculate what benefits that will bring him; adheres to principles without hurrying after success." 33 As some commentators have already pointed out, what the History of the Former Han calls "not striving for success [at all]" means something quite different from "not hurrying after success" in the Luxuriant Gems, and Dong's original meaning is best reflected by the latter. ${ }^{34}$ Moreover, in my view, what is much more important to note here is the fact that Dong uses the ideas of "not calculating benefits" and "not striving (or hurrying) after success" to describe a "humane person." In other words, Dong can be seen as building on Confucius's notion that "a humane person understands rightness, whereas a petty person understands benefit." At the same time, he also understood something about the "strange phenomenon" in the human pursuit of benefit to which Mengzi draws our attention. Like Menzi, Dong contrasts the different ways in which exemplary persons (e.g., Confucius's disciples Yuan Xian 原憲, Zeng Shen 曾參, and Min Sun 閔損) and petty persons ("the common people" [xiaomin 小民]) pursue benefit and their varying degrees of success. In Dong's view, common people "forget rightness and deliver themselves over to benefit" and thus bring disaster upon themselves:

In giving birth to people, Heaven sustains them by giving birth to rightness and benefits: Material benefits to nourish their bodies; righteous principles to nourish their hearts. If the heart does not obtain righteous principles, it cannot be joyful; if the body does not obtain material benefits, it cannot be secure. Righteous principles are the heart's nourishment; material benefits are the body's nourishment. With regard to the body, nothing is more exalted than the heart. With regard to nurture, nothing is more important than righteous principles, more important than material benefits. How do we know this to be true? When people amply possess rightness but sorely lack benefits, though poor and humble, they still may bring honor to their conduct, thereby cherishing their persons and rejoicing in life. Those like Yuan Xian, Zeng Shen, and Min Sun exemplify this. When people amply possess material benefits but utterly lack righteous principles, though exceedingly wealthy, they are insulted and despised.

$33 \mathrm{Su} \mathrm{Yu}$ 蘇輿, Chunqiu fanlu yizheng 春秋繁露義證 [Verified Meaning of the Luxuriant Gems of the Spring and Autumn], coll. Zhong Zhe 鐘哲 (Beijing: Zhonghua shuju, 2015), 262. Translation, with modifications, taken from Sarah A. Queen and John S. Major, trans. and ed., Luxuriant Gems of the Spring and Autumn (New York: Columbia University Press, 2016), 328. - Trans.

34 See Li Zehou 李澤厚, Zhongguo gudai sixiang shi lun 中國古代思想史論 [Essays on the History of Ancient Chinese Thought] (Beijing: Renmin chubanshe, 1985), 151. 
If their misdeeds are excessive, their misfortunes are serious. If they are not executed for their crimes, they [nevertheless] are struck down by an early death. They can neither rejoice in life nor live out their years. People who are punished with execution or die prematurely exemplify this. Now those who possess righteous principles, although poor, are able to find joy in themselves, but those who utterly lack righteous principles, although wealthy, are not able to preserve themselves. I rely on such examples to substantiate the claim that for nourishing and sustaining the people, righteous principles are more important than material benefits and more beneficial than wealth. But [ordinary] people are incapable of knowing this, so they constantly get it backward; they all forget righteous principles and deliver themselves over to material benefits, disregard inherent principles and follow evil ways, thereby harming themselves and endangering their families. It is not that they personally intend to be disloyal [to their families] but that this is a matter their knowledge is incapable of understanding. ${ }^{35}$

For Dong Zhongshu, the problem with "common people" is the fact that they are ignorant ("their knowledge is incapable of understanding") and have a very narrow understanding of "benefit," namely material benefit (goods and riches). They remain ignorant of spiritual benefits, including rightness as "the heart's nourishment." What Dong leaves unexplained here is why "petty persons" bring disaster upon themselves by pursuing material benefit. In effect, this question as already adequately answered in Mengzi's description of the "irresistible urge to lay claim to more" in his admonitions to King Hui. As we learn from the Mengzi, a rational utilitarianist has to commit to what the Mozi calls "the exchange of mutual benefit," instead of blindly pursuing one's own limited interest as a "petty person" or "naïve utilitarianist" would do. Confucianism and Mohism both reject such a "naïve utilitarianism" and uphold a kind of "deliberated utilitarianism."

Translated by Ady Van den Stock 


\section{Works Cited}

Ahern, Dennis M. “Is Mo Tzu a Utilitarian?” Journal of Chinese Philosophy 3, no. 2 (1976): 185-93.

Ban $\mathrm{Gu}$ 班固. Hanshu 漢書 [History of the Former Han]. Annotated by Yan Shigu 顔師古. Beijing: Zhonghua shuju, 1962.

Bloom, Irene, trans., and Philip J. Ivanhoe, ed. Mencius. New York: Columbia University Press, 2009.

Duan Yucai 段玉裁. Shuowen jiezi zhu 說文解字注 [Annotated Edition of Explaining Graphs and Analyzing Characters]. Beijing: Zhonghua shuju, 2013.

Durrant, Stephen, Wai-yee Li, and David Schaberg, trans. Zuo Tradition: Commentary on the Spring and Autumn Annals. Seattle: University of Washington Press, 2016.

Fraser, Chris. "Mohism." In Stanford Encyclopedia of Philosophy. https://plato.stanford .edu/entries/mohism//\# ethics/. Last modified October 21, 2002.

Hao Changchi 郝長墀. "Mozi shi gonglizhuyizhe ma? Lun Mojia lunli sixiang de xiandai yiyi 墨子是功利主義者嗎? 論墨家倫理思想的現代意義 [Is Mozi a Utilitarian? On the Contemporary Significance of Mohist Ethics]." Zhongguo zhexue shi 中國哲 學史, no. 1 (2005): 70-78.

Hong Liangji 洪亮吉. Chunqiu zuozhuan gu 春秋左傳詁 [Interpretation of the Spring and Autumn Annals and the Zuo Commentary]. Collated by Li Jiemin 李解民. Beijing: Zhonghua shuju, 1987.

Jiao Xun 焦循. Mengzi zhengyi 孟子正義 [The Correct Meaning of the Mengzi]. Collated by Shen Wenzhuo 沈文倬. Beijing: Zhonghua shuju, 1987 .

Johnson, Daniel M. "Mozi's Moral Theory: Breaking the Hermeutical Stalemate." Philosophy East and West 61, no. 2 (2011): 347-64.

Johnston, Ian, trans. The Mozi: A Complete Translation. Hong Kong: Chinese University Press, 2010.

Legge, James, trans. The Book of Changes. https://ctext.org/book-of-changes/.

Li Zehou 李澤厚. Zhongguo gudai sixiang shi lun 中國古代思想史論 [Essays on the History of Ancient Chinese Thought]. Beijing: Renmin chubanshe, 1985 .

Liu Baonan 劉寶楠. Lunyu zhengyi 論語正義 [Correct Meaning of the Analects]. Collated by Gao Liushui 高流水. Beijing: Zhonghua shuju, 199 o.

Nie Tao 聶鞱. “Mozi 'gongli zhuyi' sixiang yanjiu de yingyu shuxie 墨子 ‘功利主義” 思想研究的英語書寫 [English-Language Scholarship on Mozi's 'Utilitarianism'].” Sichuan shifan daxue xuebao 四川師範大學學報, no. 3 (2015): 19-30.

Queen, Sarah A., and John S. Major, trans. and ed. Luxuriant Gems of the Spring and Autumn. New York: Columbia University Press, 2016.

Ruan Yuan 阮元, ed. Shisan jing zhushu 十三經注疏 [Annotations and Commentaries on the Thirteen Classics]. Shanghai: Shanghai guji chubanshe, 1997. 
Sinnott-Armstrong, Walter. "Consequentialism." In Stanford Encyclopedia of Philosophy. https://plato.stanford.edu/entries/consequentialism/. Last modified June 3, 2019.

Slingerland, Edward. Confucius: Analects, with Selections from Traditional Commentaries. Indianapolis: Hackett, 2003.

Soles, David E. "Mo Tzu and the Foundation of Morality." Journal of Chinese Philosophy 26, no. 1 (1999): 37-48.

$\mathrm{Su} \mathrm{Yu}$ 蘇輿. Chunqiu fanlu yizheng 春秋繁露義證 [Verified Meaning of the Luxuriant Gems of the Spring and Autumn]. Collated by Zhong Zhe 鐘哲. Beijing: Zhonghua shuju, 2015.

Sun Yirang 孫詒讓. Mozi jiangu 墨子閒詁 [Annotations to the Mozi]. Collated by Sun Qizhi 孫啓治. Beijing: Zhonghua shuju, 2001.

Xu Yuangao 徐元誥. Guoyu jijie 國語集解 [Collected Commentaries on the Discourses of the States]. Collated by Wang Shumin 王樹民 and Shen Changyun 沈長雲. Beijing: Zhonghua shuju, 2002.

Yang Bojun 楊伯峻. Lunyu yizhu 論語譯注 [An Annotated Translation of the Analects]. Beijing: Zhonghua shuju, 2006.

Zhu Xi 朱喜. Sishu zhangju jizhu 四書章句集注 [Section and Sentence Commentaries and Collected Annotations on the Four Books]. Beijing: Zhonghua shuju, 1983.

Zhu Xi 朱喜. Zhuzi quanshu 朱子全書 [The Complete Works of Zhu Xi]. Shanghai: Shanghai guji chubanshe; Hefei: Anhui jiaoyu chubanshe, 2002. 